\title{
Breast cancer risk factors that are identical and differential associated with menopause status of women in Northeast Brazil
}

\section{Kedma Anne Lima Gomes}

State University of Paraíba (UEPB)

Aline Ferreira de Araújo Jerônimo

State University of Paraíba (UEPB)

\section{Raissa de Oliveira Ramos}

State University of Paraíba (UEPB)

Lorena Sofia dos Santos Andrade

State University of Paraíba (UEPB)

Mathias Weller ( $\square$ mathiasweller@uepb.edu.br)

State University of Paraíba (UEPB) https://orcid.org/0000-0002-5881-4256

\section{Research article}

Keywords: Breast Cancer, Reproductive risk factors, Life-style related risk factors, Menopause

Posted Date: September 11th, 2019

DOI: https://doi.org/10.21203/rs.2.14276/v1

License: (우 (i) This work is licensed under a Creative Commons Attribution 4.0 International License. Read Full License 


\section{Abstract}

Background: This case-control study was aimed at the identification of factors that modify breast cancer risk in a population from Northeastern Brazil. Breast cancer risk factors in this population are poorly understood.

Methods: Data of 291 patients with invasive breast cancer and 291 healthy controls were obtained from medical records and personal interviews. Odds ratios (OR) and confidence intervals ( $\mathrm{Cl}$ ) were determined using univariate and multiple regression analysis.

Results: Oral contraceptive use increased the risk of breast cancer among pre- and post-menopause women 3.661 (95\% Cl: 1.81-7.39; $\mathrm{p}<0.001)$ and 3.086 (95\%Cl: 1.85-5.79; $\mathrm{p}<0.001)$ times. Family history increased the risk of breast cancer among pre- and post-menopause women 3.791 (95\% Cl: 1.85-7.77; $p<0.001)$ and 3.538 (95\% Cl: $2.16-5.79 ; p=0.000)$ times. Risk of breast cancer among post-menopause women who regularly consumed alcohol was 4.21 (95\% Cl: $2.08-8.50 ; p<0.001)$ times increased compared to women who did not consume alcohol. Obese and overweight post-menopause women had 2.117 (95\%Cl: 1.153.88 ) and 1.217 (95\% Cl: 0.74-2.19) times increased risk, compared to women with normal weight ( $p=$ 0.044). Waist-to-hip ratio $>0.8$ increased the risk of breast cancer among pre- menopause women 2.026 (0.94-4.38; $p=0.067)$ times in the univariate analysis. Nulliparous post-menopause women had 2.667 (95\% Cl: $1.30-5.50 ; p=0.070)$ times increased risk. Univariate analysis of nulliparity among pre-menopause women indicated $2.59(\mathrm{OR}=0.386 ; 95 \% \mathrm{Cl}: 0.15-0.98 ; \mathrm{p}=0.038)$ times decreased risk.

Conclusions: Oral contraceptive use, family history and alcohol consumption increased the risk of breast cancer among pre- and post-menopause women. High body mass index increased the risk only among post-menopause women, whereas unadjusted high waist-to-hip ratio increased the risk of pre- menopause women. Nulliparous pre-menopause women tended to have decreased risk, whereas nulliparous postmenopause women tended to have increased risk of breast cancer.

\section{Background}

Breast cancer (BC) is the most common cancer worldwide and between 2005 and 2015, the disease incidence increased from 1.7 to 2.4 million cases worldwide [1]. This increase was mostly observed in developing countries due to changing lifestyle and longer life expectation, whereas in most developed countries, the incidence remained stable, or even declined [2]. With more than 209 million inhabitants, Brazil is the largest country of Latin American. For the year 2018, 59,700 new cases of the disease were predicted and $B C$ is currently contributing to $29.5 \%$ of all neoplasms among women [3]. In the two largest urban centers of Brazil, São Paulo, respectively, Rio de Janeiro and also other regions in Southern, Southeastern and Midwestern Brazil, over the last 10 years, BC incidence has stabilized [3]. This is in contrast to the Northeastern region, where BC incidence increased between 2005 and 2018 from 27.23 to 63.98 new cases per 100,000 women $[3,4]$.

In literature, it is well established that reproductive, respectively, anthropometric and lifestyle related factors, modify the risk of $\mathrm{BC}[5-8]$. It was estimated that about one third of all post- menopausal BC cases in the 
United States are caused by modifiable and therefore preventable, lifestyle-related risk factors [9]. In the United Kingdom, $6.9 \%$ of all breast cancer cases were attributed to obesity and overweight, as a single risk factor for the disease [6]. Brazilian case-control BC studies identified family history, poor diet, low physical activity, high body mass index (BMI), alcohol consumption, low versus high number of children and use of oral contraceptives, as risk factors for the disease [10 - 12]. These studies referred to data from populations from Southern and Southeastern regions of Brazil. Only few studies addressing the identification of risk factors were performed in Northeastern Brazil, a region where BC incidence is increasing: Lima and colleagues (2008), attributed increased BC risk to poor diet of women, including high intake of red and processed meat [13]. A recent case-control study of a population from Northeastern Brazil identified menarche age $\leq 12$ years, one versus $\geq 2$ children and time interval before first and last gestation of $>10$ years as risk factors for $\mathrm{BC}$, whereas total lifetime breastfeeding $>24$ month decreased the risk of $\mathrm{BC}$ [14]. Another recent study identified obesity and overweight as risk factor for BC [15].

Since 2003, Brazil has a public program for early detection of breast cancer and mammography screening is propagated in the month of October ("Outubro rosa"). In Northeastern Brazil, most women rely on information about $\mathrm{BC}$ on television and very few information is given about preventable risk factors, respectively modifiable factors that decrease the risk of $B C$ [16]. There is an urgent need to identify $B C$ risk factors in this population and if modifiable, to propagate their prevention in health campaigns. The present case- control study focused on identification of lifestyle-related and reproductive risk factors in a population from Northeastern Brazil. The identification of several risk factors indicates remarkable differences of pre- and post menopause women that were not reported in previous studies with any Brazilian population.

\section{Methods}

\section{Study population}

Patients were eligible if diagnosed within 36 months from recruitment with invasive $B C$ and aged 18 years or older. Patients with in situ tumors were excluded from the study. Patients with breast cancer recurrence were also excluded from the study. Data from breast cancer patients were sampled in two reference centers for breast cancer treatment in the state of Paraíba, Northeastern Brazil: The "Fundação Assistencial da Paraíba" Hospital (FAP) in Campina Grande and "Napoleão Laureano" Hospital (HNL) in João Pessoa. Both public hospitals receive mainly low- income patients and treat more than $95 \%$ of all BC cases in the state. Patients seeking for treatment come from regions as far as $600 \mathrm{~km}$ from the reference centre. João Pessoa, capital of the state of Paraíba, has about 0.8 million inhabitants and is located on the coast. Campina Grande, with about 0.4 million inhabitants, the second most populated urban centre in Paraíba, is located about $120 \mathrm{~km}$ away from the capital in the inland of the state. Similarly to other states of Northeastern Brazil, Paraíba has mixed-ethnicity population composed of Indigenous, African and European ancestry.

Data of controls were obtained from both public hospitals and in three public health care centers. Many patients were from rural areas. Therefore, a comparable part of controls was also recruited from rural areas: Two of the three health care centers were in rural areas, about $40 \mathrm{~km}$ away from Campina Grande. Women 
with any type of cancer were excluded from the study as controls. Women with any other chronic disease, like diabetes and heart disease were also excluded as controls. Furthermore, it was avoided to interview more than one healthy women of the same family. Controls were randomly selected in health care centers and directly asked by one of the authors to participate as volunteers. Most controls $(>60 \%)$ accompanied children or grandchildren for vaccine or other medical examination. Other controls visited the health care center mainly because of injuries, colds or gastrointestinal infections. Controls interviewed in hospitals were healthy companions of non-cancer patients. Controls were eligible for the study if they were aged over 18 years old and agreed to participate in the study. Participation rate of patients and controls was about $90 \%$ and $85 \%$.

\section{Data sampling}

Breast cancer patients and controls were interviewed between March 2017 and January 2019. The study included 291 women with invasive operable breast cancer, diagnosed and treated between 2016 and 2019. No significant differences were observed between patients of both reference centers. A structured questionnaire was applied to interview patients in chemotherapy and radiotherapy units of both hospitals. Clinical and histopathological data of patients were obtained from medical records. Height and weight had been measured in both reference centers before any therapeutic treatment and were also obtained from medical records. The same questionnaire was applied to interview healthy controls in waiting rooms of health care centers. All interviews were performed by one of the authors.

Body mass index (BMI) was defined according to the World Health Organization [17]: Underweight: $<18.5$ $\mathrm{kg} / \mathrm{m}^{2}$; normal weight: $18.5-24.99 \mathrm{~kg} / \mathrm{m}^{2}$; overweight: $25.0-29.99 \mathrm{~kg} / \mathrm{m}^{2}$; obesity $\geq 30.0 \mathrm{~kg} / \mathrm{m}^{2}$. Waist-tohip ratio (WHR) was defined according to previous studies [20]: Normal weight: $\leq 0.8$; Obesity and overweight: $>0.8$.

Minimum wage and multiple values were used to characterize income. This is a popular and well-known method to define economic level among low- and middle-class subjects. Information about ethnic origin was self-reported by participants. Educational level was defined as follows: 1. Incomplete elementary school with duration of less than nine years was defined as "Basic"; 2 . Elementary school with duration of nine years was defined as "Low" 3 . High school with duration of 12 years was defined as "middle". 4. Higher educational levels were defined as "high". Data about ethnic origin were self-reported by participants. Women were asked if they used ever or never oral contraceptives. When asked about family history, interviewed women often confounded BC with other types of cancer. Therefore present information about family history referred to different types of cancer and not to $B C$ alone. Family history included BC and other types of cancer among first- degree relatives. Physical activity was defined as any type of regular low, moderate or strong body movement.

\section{Statistical analysis}


All statistical analyses were performed using the SPSS STATISTICS ${ }^{\text {TM }}$ software (SPPS; IBM company; version 24). The t-test was applied to compare continuous variables. Pearson's Chi-Square ( $\chi 2)$ test was applied to compare categorized variables. To quantify associations among single risk factors for $\mathrm{BC}$, nominal logistic regression analysis was applied. Data of controls served as reference group. Results were presented as adjusted odd ratios (OR), 95\% confidence interval (Cl) and p-value of likelihood ratio tests. Significant univariate regression analysis variables were used for regression modeling with multiple adjusted variables: Variables with significance level less than 0.2 in the univariate analysis were included in the model. Then, variables with significance level less than 0.05 were kept in the model. Backward selection was used when significant variables were selected. The final model was tested for fitness using the likelihood ratio test.

\section{Results}

Basic socio- demographic and anthropometric characteristics of cases and controls were summarized in Table 1. Of all 582 women, 181 showed pre-menopause status, whereas 401 showed post-menopause status (Table 1). As variables of pre- and post-menopause women showed remarkable differences, data were stratified for menopause status. Mean waist-to-hip ratio (WHR) of 88 pre-menopause cases was 0.872 ( $s=0.07)$ compared to $0.848(s=0.08)$ of 93 controls $(p=0.036$; Table 1$)$. Of all pre-menopause women, $28(31.82 \%)$ cases and $16(17.20 \%)$ controls informed Caucasian ethnic origin ( $p=0.025$; Table 1$)$. The mean age of 203 post-menopause cases and 198 controls was $59.70(s=10.09)$ and $62.15(s=9.84)$ years ( $p=0.015$; Table 1). The mean body mass index (BMI) of post-menopause cases and controls was 28.31 ( $s$ $=5.20)$ and $26.67(\mathrm{~s}=4.58)(p=0.001$; Table 1$)$. In contrast to pre-menopause women, WHR and marital status were not significantly different between post-menopause cases and controls $(p=0.149 ; p=0.055$; Table 1). Of the 401 post-menopause women, 131 (64.53\%) cases and $152(76.77 \%)$ controls had low income $(p=0.026)$.

In the univariate regression analysis, pre-menopause nulliparous women had $2.59(\mathrm{OR}=0.386 ; 95 \% \mathrm{Cl}$ : $0.15-0.98)$ decreased risk of BC compared to parous women ( $p=0.038$; Table 2$)$. The comparison of WHR among pre- menopause women indicated that those with value $>0.8$, had 2.026 (95\% Cl: 0.94-4.38) times increased risk of the disease, compared to women with WHR of $\leq 0.8(p=0.067$; Table 2$)$. In the adjusted multiple analysis model, only variables oral contraceptive use, family history and alcohol consumption remained heterogeneously distributed between pre-menopause cases and controls (Table 2): Oral contraceptive use and family history increased the risk of BC by 3.610 (95\% Cl: 1.77-7.38) and 3.791 (95\%Cl: 1.85-7.77) times, compared to women who claimed not to have used oral contraceptives before disease diagnosis, respectively, without family history $(p<0.001 ; p<0.001$; Table 2$)$. Consumption of alcohol increased risk of BC 2,059 (95\% Cl: 0.90-4.73) times, compared to women who never consumed it $(p=0.086 ;$ Table 2$)$.

In the group of post-menopause women with age at menarche $<12$ years, the risk of the disease increased 1.918 (95\% Cl: $1.01-3.66)$ times compared to women with age at menarche $\geq 12$ years $(p=0.044$; Table 2$)$. In the adjusted multiple analysis model, variables nulliparity, oral contraceptive use, family history, BMI and alcohol consumption remained heterogeneously distributed between post-menopause cases and controls 
(Table 2): In contrast to pre- menopause women, nulliparity tended to increase the risk of BC among postmenopause women. Nulliparous women had 2.667 (95\% Cl: 1.30-5.50) times increased risk of the disease compared to parous women ( $p=0.070$; Table 2). Post-menopause women, who used oral contraceptives and had positive family history of $\mathrm{BC}$, had $3.086(95 \% \mathrm{Cl}: 1.85-5.79)$ and $3.576(95 \% \mathrm{Cl}: 2.21-5.79)$ times increased risk of the disease ( $p<0.001 ; p<0.001 ;$ Table 2$)$. In contrast to pre-menopause women, increased $\mathrm{BMI}$ among post-menopause women was positively associated with risk of the disease: Obese and overweight women had 2.117 (95\% Cl: $1.15-3.88)$ and 1.271 (95\% Cl: $0.74-2.19)$ increased risk of the disease compared to women with normal weight $(p=0.048$; Table 2). Post-menopause women who consumed any type of alcohol had 4.21 (95\% Cl: 2.08-8.50) times increased risk of the disease compared to those who did not consume alcohol $(p<0.001$; Table 2$)$.

Breastfeeding had no significant impact on risk of $\mathrm{BC}$ among parous women ( $p=0.081$ Table 2). Parous cases and controls had on average $3.27(s=2.21)$ and $3.12(s=2.56)$ children $(p=0.479)$, respectively. In the multiple analysis model, women with one and two, respectively three children, had a $2.52(\mathrm{OR}=0.397$; $95 \% \mathrm{Cl}: 0.21-0.76)$ and $1.61(\mathrm{OR}=0.621 ; 95 \% \mathrm{Cl}: 0.38-1.02)$ times decreased risk of disease compared to women with more than three children ( $p=0.016$; Table 2). Similarly, as in the case of post- and premenopause women, oral contraceptive use, family history and alcohol consumption were associated with increased risk of the disease $(p<0.001 ; p<0.001 ; p<0.001 ;$ Table 2$)$.

Of all 582 women, $189(64.95 \%)$ cases and $98(33.68 \%)$ controls had used contraceptives $(p=0.000)$. The mean time of oral contraceptive use between cases and controls was $69.15(\mathrm{~s}=67.57)$ and $82.79(\mathrm{~s}=$ $68.99)$ months $(p=0.101)$, respectively. Of all 582 women, $86(29.55 \%)$ cases and $26(8.94 \%)$ controls consumed alcohol $(p=0.000)$. Alcohol consumption between cases and controls was on average $4.74(\mathrm{~s}=$ $5.16)$ and $3.08(s=5.36)$ times per month $(p=0.168)$.

\section{Discussion}

In the present study, oral contraceptive use, family history and alcohol consumption were positively associated with risk of BC. Their effect was similar among pre- and post- menopausal parous women, respectively. Anthropometric measures $\mathrm{BMI}$ and WHR in contrast, were differently associated with risk of BC between pre- and post-menopause women. Reproductive risk factors age at menarche and nulliparity also showed remarkable differences between pre- and post-menopause women.

Age at menarche $<12$ years increased the risk of the disease among post-menopause women, but not among pre-menopause women. However, this effect remained not significant after data adjustment. In agreement with present results, recent studies carried out in Thailand, Brazil and Norway revealed increased risk of $B C$ associated with younger age at menarche $[14,19,20]$.

Post-menopause nulliparous women of the present study had increased risk of the disease. Among premenopause women in contrast, nulliparity as a single variable, decreased the risk of $\mathrm{BC}$, but had no significant effect after data adjustment. Parity is a well- established modulator of risk of BC [21]. Previous studies have associated nulliparity with an overall increased risk of the disease [20,22]. Nulliparity as a risk 
factor for BC was also identified in a previous study carried out in Brazil [14]. Furthermore, the effect of parity depends on menopause status: Parous pre-menopause women, mainly at the age of 35 or older, had increased risk of the disease until 15 years after delivery [23]. Among post-menopause women in contrast, nulliparity was associated with increased risk of the disease, explaining the general protective effect of parity, as most BC cases are found among post-menopause women [21]. The dual effect of parity that depends on menopause status, may be also present in the present population, reducing risk among premenopause women, increasing the risk among post-menopause women, respectively. However, present data indicated the effect of parity, comparing nulliparous and parous women, but did not establish a positive association between high number of children and reduced risk among post-menopause women. Furthermore, in contrast to present results the protective effect of parity among parous women generally increases with higher number of children [21].

The use of oral contraceptives increased the risk of BC between pre- and post-menopause women in the present study. Previous findings support the idea that the use of oral contraceptives increases the risk of $B C$ : In literature, oral contraceptive use is a well-established risk factor for $B C[5,19,22]$. A previous Brazilian study also identified oral contraceptive use for more than five years as risk factor for $B C$ among women aged $\geq 45$ years [24]. Studies have indicated that the risk of $B C$ increases only during or after recent use: Recent use of oral contraceptives was associated with increased risk of the disease among young women [25]. An observational study conducted for more than four decades in the United Kingdom showed that the risk of $B C$ decreased approximately five years after stopping use of oral contraceptives [26]. Present data also indicated that positive family history increased the risk of BC of both pre- and postmenopause women. In agreement with present results, recent studies performed in Thailand and Brazil, also identified first- degree family history of $\mathrm{BC}$ as a variable that increased the overall risk of the disease $[10,19]$.

According to the World Health Organization (WHO), between 2010 and 2014, overweight and obesity increased from $51.10 \%$ to $54.10 \%$, respectively, from $17.80 \%$ to $20.00 \%$ among Brazilian adults [17]. In the present study, antrophometric measures BMI and WHR showed differences between pre- and postmenopause women: Results have indicated that obesity and overweight, determined as $\mathrm{BMI}$, was positively associated with risk of $\mathrm{BC}$ among post- menopause women, but not among pre- menopause women. Obesity and overweight are considered the most important modifiable lifestyle-related risk factor among women, especially due to its impact on BC [6]. In studies that used anthropometric measures, obesity and overweight increased the overall risk of $B C[15,19,20,22]$. A recent study performed in Southern Brazil, associated obesity, respectively high $\mathrm{BMI}$, to increased risk of $\mathrm{BC}$ among post-menopause women and to decreased risk of BC among pre-menopause women [11]. Similarly, recent studies, all based on BMI, identified obesity and overweight as risk factors for $\mathrm{BC}$ among post- menopause women, whereas results for pre- menopause women remained conflicting $[5,27]$. A recent study performed in the United Kingdom revealed that low BMI and low waist-to-hip ratio increased the risk of pre-menopause women, whereas both measures were positively associated with risk of BC among post-menopause women [6]. In a metaanalysis, Amadou and colleagues (2013) pointed out that increased BMI of post-menopause women was positively associated with $\mathrm{BC}$, whereas high WHR increased the risk of both pre-menopause and post- 
menopause women [18]. The present results about BMI, were consistent with most previous studies. However, in the case of WHR, univariate analysis of present data indicated borderline significance among pre-menopause women, but not among post- menopause women. Only obese pre-menopause women tended to have increased risk of the disease.

Pre- and post-menopause women of the present study, who consumed some type of alcohol, had increased risk of the disease. This effect was strong for post-menopause women, but week for pre-menopause women. A recent study carried out in Rio de Janeiro, Brazil, also identified alcohol consumption as a risk factor for BC [12]. A previous study indicated that even low doses of alcohol could increase the risk of BC and that there is a positive relationship between dose of alcohol and risk of the disease [28]. The effect of alcohol on the etiology of BC could be by epigenetic mechanisms [29]. A recent study on pre-menopause women suggested that alcohol had negative effect only on individuals who also had family history of BC and lower folic acid intake [30]. Therefore, the effect of alcohol depends on the context of other risk factors and this may also explain why in other previous studies, alcohol consumption had no impact on the risk of $\mathrm{BC}[30]$.

The low availability of data may have impaired the establishment of a positive association between dose of alcohol consumption and risk of BC. It was also not possible to identify any possible protective effect of breastfeeding and high number of children for parous and post-menopause women, respectively. Low number of data generally leads to lower resolution and therefore may have obscured significant associations between $\mathrm{BC}$ and such factors. The study established an overall positive association between use of oral contraceptives and risk of $\mathrm{BC}$, but important data about the time interval between last use of oral contraceptives and disease diagnosis were missing. The study included patients who received diagnosis of disease within the last three years. Therefore, another limitation of the present study may have been recall biases of interviewed women and information about risk factors may have been confounded. Furthermore, a selection bias of controls and patients cannot be excluded.

\section{Conclusion}

The present results indicated that family history and several lifestyle-related factors increased the risk of BC among women in this study: Family history and oral contraceptive use increased the risk of BC among post- and pre-menopause women. Increased risk of women, who consumed alcohol, was more pronounced among post-menopause than pre- menopause women. Obesity and overweight, measured by BMI, increased the risk of $\mathrm{BC}$ among post-menopause women, but not among pre-menopause women. In the univariate analysis, early age at menarche increased the risk of $\mathrm{BC}$ among post-menopause women and WHR had borderline significance among pre-menopause women. Nulliparity increased risk of postmenopause women and reduced risk of pre- menopause women. These findings are in agreement with most previous case-control studies about risk factors for BC. Future studies should include larger groups of patients and controls. Furthermore, regarding alcohol consumption, the effect of different doses should be analyzed and in the case of oral contraceptive use, time interval between last use and BC diagnosis should be integrated. Avoiding modifiable behaviors such as alcohol consumption and poor diet should be 
propagated by health authorities mainly during public health campaigns like "Outubro Rosa", that focuses so far nearly exclusively on mammography screening, but not on risk factors.

\section{Abbreviations}

MS: Mammography screening.

\section{Declarations}

\section{Acknowledgements}

We would like to thank all women who participated in this study. We also would like to thank the staff of "Fundação Assistencial da Paraíba" and "Napoleão Laureano" public hospitals and health service centers that supported this study.

\section{Ethical approval and consent to participate}

The data sampling protocol was reviewed and approved by the Brazilian National Ethics Research Committee (CAAE plataforma Brasil: 22358113.1.0000.5187). Written informed consent was obtained from each participant of the study.

\section{Consent for publication}

Consent to publish data anonymously was obtained from each participant of the study.

\section{Availability of data}

The datasets used during the current study are available from the corresponding author on reasonable request.

\section{Competing interests}

The authors declare that they have no interests that compete with any of the contents of the manuscript.

\section{Funding}

This work was funded by the Brazilian "Coordenação de Aperfeiçoamento de Pessoal de Nível Superior (CAPES)". 


\section{Authors' contributions}

KALG, AFAJ, ROR and LSSA performed interviews and tabulation of data. KALG and MW performed data analysis. MW performed study design and manuscript draft. Authors equally contributed to conception and critical review of the manuscript. All authors read and approved the final manuscript.

\section{References}

1. Fitzmaurice C, Allen C, Barber RM, Barregard L, Bhutta ZA, Brenner H et al. Global, Regional, and National Cancer Incidence, Mortality, Years of Life Lost, Years Lived With Disability, and Disability-Adjusted Life-years for 32 Cancer Groups, 1990 to 2015. A Systematic Analysis for the Global Burden of Disease Study. JAMA Oncol 2017, 3(4):524-548. doi:10.1001/jamaoncol.2016.5688.

2. Torre LA, Sauer AM, Chen MS Jr, Kagawa-Singer M, Jemal A, Siegel RL. Cancer statistics for Asian Americans, Native Hawaiians, and Pacific Islanders, 2016: Converging incidence in males and females. CA Cancer J Clin 2016, 66(3):182-202. doi: 10.3322/caac.21335. PMID: 26766789.

3. Instituto Nacional de Câncer (INCA, 2019). Estimativa 2019: Incidência de câncer no Brasil. [http://www1.inca.gov.br/estimative/2018/estimative-2018.pdf].

4. Instituto Nacional de Câncer (INCA, 2005). Estimativa 2019: Incidência de câncer no Brasil. [http://www1.inca.gov.br/vigilancia/docs/portugal2005/estimativa\%202005.pdf].

5. Al-Ajmi K, Lophatananon A, Ollier W, Muir KR. Risk of breast cancer in the UK biobank female cohort and its relationship to anthropometric and reproductive factors. PLOS ONE 2018, 13(7): e0201097. doi.org/10.1371/journal.pone.0201097.

6. Parkin DM. The fraction of cancer attributable to lifestyle and environmental factors in the UK in $2010 . \mathrm{Br}$ J Cancer 2011, 105(S2). doi:10.1038/bjc.2011.474. PMID: 22158314.

7. Olver IN. Prevention of breast cancer. Med J Aust 2016, 205(10):475-479. doi: 10.5694/mja16.01007.

8. Costa M, Saldanha P. Risk Reduction Strategies in Breast. Cancer Prevention. Eur J Breast Health 2017, 13(3):103-112. doi: 10.5152/ejbh.2017.3583.

9. Tamimi RM, Spiegelman D, Smith-Warner SA, Wang M, Pazaris M, Willett WC, Eliassen AH et al. Population Attributable Risk of Modifiable and Nonmodifiable Breast Cancer Risk Factors in Postmenopausal Breast Cancer. Am J Epidemiol 2016, 184(12):884-893. doi:10.1093/aje/kww145.

10. Inumaru LE, Gomes Duarte Quintanilha MI, da Silveira EA, Veloso Naves MM. Risk and Protective Factors for Breast Cancer in Midwest of Brazil. J Environ Pub Health 2012. doi:10.1155/2012/356851.

11. Gravena AAF, Lopes TCR, Demitto MO, Borghesan DHP, Dell' Agnolo CM, Brischiliari SCR et al. The Obesity and the Risk of Breast Cancer among Pre and Postmenopausal Women. Asian Pac J Cancer Prev 
2018, 19(9).2429-2436. doi:10.22034/APJCP.2018.19.9.2429. PMID: 30255696.

12. Vieira R, Tobar JSS, Dardes R, Claudio L, Thuler S. Alcohol consumption as a risk factor of breast cancer development: A case- control study in Brazil. Asian Pac J Cancer Prev 2018, 19(3):703-7.

13. Lima FEL, Latorre MRDO, Costa MJC, Fisberg RM. Dieta e câncer no Nordeste do Brasil: avaliação da relação entre alimentação e consumo de grupos de alimentos e câncer de mama. Cad Saúde Pública 2008, 24(4):820-828. doi:10.1590/S0102-311X2008000400012.

14. Almeida GS, Almeida LAL, Araújo GMR, Weller M. Reproductive Risk Factors Differ Among Breast Cancer Patients and Controls in a Public Hospital of Paraiba, Northeast Brazil. Asian Pac J Cancer Prev 2015, 16(7).2959-2965. doi:10.7314/APJCP.2015.16.7.2959.

15. Queiroz SA, Sousa IM, Silva FRM, Lyra CO, Fayh APT. Nutritional and environmental risk factors for breast cancer: a case-control study. Sci Med 2018, 28(2):ID28723. doi:10.15448/1980-6108.2018.2.28723.

16. Freitas AG, Weller M. Knowledge about Risk Factors for Breast Cancer and Having a Close Relative with Cancer Affect the Frequency of Breast Self-Examination Performance. Asian Pac J Cancer Prev 2016, 17(4):2075-81. doi:0.7314/APJCP.2016.17.4.2075.

17. World Health Organization (2015). Obesity and overweight. Fact sheet $n^{\circ} 311$.

18. Amadou A, Torres Mejia G, Fagherazzi G, Ortega C, Angeles-Llerenas A, Chajes V et al. Anthropometry, silhouette trajectory, and risk of breast cancer in Mexican women. Am J Prev Med 2014, 46(Suppl 1):S5264. doi:10.1016/j.amepre.2013.10.024.

19. Chaveepojnkamjorn W, Thotong R, Sativipawee P, Pitikultang S. Body Mass Index and Breast Cancer Risk among Thai Premenopausal Women: a Case-Control Study. Asian Pac J Cancer Prev 2017, 18(11):3097-101. doi: 10.22034/APJCP.2017.18.11.3097.

20. Ellingjord-Dale M, Vos L, Hjerkind KV, Hjartåker A, Russnes HG, Tretli S et al. Alcohol, Physical Activity, Smoking, and Breast Cancer Subtypes in a Large, Nested Case-Control Study from the Norwegian Breast Cancer Screening Program. Cancer Epidemiol Biomarkers Prev 2017, 26(12):1736-1744. doi:10.1158/1055-9965.EPI-17-0611.

21. Kobayashi S, Sugiura H, Ando Y, Shiraki N, Yanagi T, Yamashita H et al. Reproductive history and breast cancer risk. Breast Cancer 2012, 19(4):302-8. doi:10.1007/s12282-012-0384-8.

22. Nindrea RD, Aryandono T, Lazuardi L. Breast Cancer Risk From Modifiable and Non-Modifiable Risk Factors among Women in Southeast Asia: A Meta-Analysis. Asian Pac J Cancer Prev 2017, 18(12):32013206. doi:10.22034/APJCP.2017.18.12.3201.

23. Lambe M, Hsieh CC, Trichopoulos D, Ekbom A, Pavia M, Adami HO. Transient increase in the risk os breast cancer after giving birth. N Engl J Med 1994, 331(1):5-9. 
24. Tessaroa S, Beria JU, Tomasi E, Barros AJD. Contraceptivos orais e câncer de mama: estudo de casos e controles. Rev Saúde Publica 2001, 35(1):32-38. doi:10.1590/S0034-89102001000100005.

25. Narod SA. Breast cancer in young women. Nat Rev Clin Oncol 2012, 9(8):460-70. doi:

10.1038/nrclinonc.2012.102.

26. Iversen L, Sivasubramaniam S, Lee AJ, Fielding S, Hannaford PC. Lifetime cancer risk and combined oral contraceptives: the Royal College General Practitioners' Oral Contraception Study. Am J Obstet Gynecol 2017, 216(6):80.e1-580.e9. doi: 10.1016/j.ajog.2017.02.002.

27. Cao S, Zhou J, Zhu Z, Wei F, Li W, Lu S. Adult weight change and the risk of pre-and postmenopausal breast cancer in the Chinese Wuxi Exposure and Breast Cancer Study. Breast Cancer Res Treat 2018, 173(3):647-55. doi:10.1007/s10549-018-5016-3.

28. Falk RT, Mass P, Schairer C, Chatterjee J, Mabie JE, Cunningham C et al. Alcohol and Risk of Breast Cancer in Postmenopausal Women: An Analysis of Etiological Heterogeneity by Multiple Tumor Characteristics. Am J Epidemio/ 2014, 180(7):705-717. doi:10.1093/aje/kwu189.

29. Zakhari S, Hoek JB. Epidemiology of Moderate Alcohol Consumption and Breast Cancer: Association or Causation? Cancers (Basel) 2018, 10(10):349. doi:10.3390/cancers10100349.

30. Kim HJ, Jung S, Eliassen AH, Chen WY, Willett WC, Cho E. Alcohol Consumption and Breast Cancer Risk in Younger Women According to Family History of Breast Cancer and Folate Intake. Am J Epidemiol 2017, 186(5):524-531. doi:10.1093/aje/kwx137.

\section{Tables}

Table 1. Basic socio- demographic and anthropometric characteristics of women, stratifie for menopause status. 


\begin{tabular}{|c|c|c|c|c|}
\hline \multicolumn{5}{|c|}{ Pre menopause women $(\mathrm{N}=181)$} \\
\hline & & Case $(\mathrm{N}=88)$ & Control $(\mathrm{N}=93)$ & $p$ \\
\hline Mean Age & & $42.63(\mathrm{~s}=7.93)$ & $42.68(\mathrm{~s}=8.32)$ & 0.965 \\
\hline Mean BMI & & $27.63(\mathrm{~s}=5.09)$ & $26.69(\mathrm{~s}=4.45)$ & 0.194 \\
\hline \multirow[t]{2}{*}{ Mean Waist- Hip ratio } & & $0.872(\mathrm{~s}=0.07)$ & $0.848(\mathrm{~s}=0.08)$ & 0.036 \\
\hline & & N (\%) & $\mathbf{N}(\%)$ & \\
\hline \multirow[t]{4}{*}{ Income } & Low & $56(65.88 \%)$ & $68(73.12 \%)$ & \\
\hline & Middle & $20(23.53 \%)$ & $15(16.13 \%)$ & \\
\hline & High & $9(10.59 \%)$ & $10(10.75 \%)$ & \\
\hline & Missing & 3 & & \\
\hline \multirow{2}{*}{$\begin{array}{l}\text { Private health } \\
\text { insurance }\end{array}$} & Yes & $17(19.32 \%)$ & $23(24.73 \%)$ & 0.474 \\
\hline & No & $71(80.68 \%)$ & $70(75.27 \%)$ & \\
\hline \multirow[t]{6}{*}{ Education level } & Analphabetic & 0 & $1(1.08 \%)$ & 0.680 \\
\hline & Basic & $31(35.63 \%)$ & $29(31.18 \%)$ & \\
\hline & Low & $15(17.24 \%)$ & $12(12.90 \%)$ & \\
\hline & Middle & $27(31.04 \%)$ & $33(35.48 \%)$ & \\
\hline & High & $14(16.09 \%)$ & $18(19.36 \%)$ & \\
\hline & Missing & 1 & & \\
\hline \multirow[t]{3}{*}{ Civil state } & Stable union & $56(64.37 \%)$ & $46(49.46 \%)$ & 0.051 \\
\hline & $\begin{array}{l}\text { No stable } \\
\text { union }\end{array}$ & $31(35.63 \%)$ & 47 (50.54\%) & \\
\hline & Missing & 1 & & \\
\hline \multirow[t]{2}{*}{ Ethnic origin } & Mixed & $60(68.18 \%)$ & 77 (82.80\%) & 0.025 \\
\hline & Caucasian & 28 (31.82\%) & 16 (17.20\%) & \\
\hline
\end{tabular}

\section{Post menopause women $(\mathrm{N}=401)$}

\begin{tabular}{|l|l|l|l|l|}
\hline & & Case $(\mathbf{N}=203)$ & Control $(\mathbf{N}=198)$ & \\
\hline Mean Age & & $59.70(s=10.09)$ & $62.15(s=9.84)$ & 0.015 \\
\hline Mean BMI & & $28.31(s=5.20)$ & $26.67(s=4.58)$ & 0.001 \\
\hline Mean Waist- Hip ratio & & $0.894(s=0.06)$ & $0.886(s=0.06)$ & 0.149
\end{tabular}




\begin{tabular}{|c|c|c|c|c|}
\hline & & $\mathbf{N}(\%)$ & $\mathbf{N}(\%)$ & \\
\hline \multirow[t]{3}{*}{ Income } & Low & $131(64.53 \%)$ & $152(76.77 \%)$ & 0.026 \\
\hline & Middle & $64(31.53 \%)$ & 40 (20.20\%) & \\
\hline & High & $8(3.94 \%)$ & $6(2.03 \%)$ & \\
\hline \multirow{2}{*}{$\begin{array}{l}\text { Private health } \\
\text { insurance }\end{array}$} & Yes & 27 (13.30\%) & 21 (10.61\%) & 0.249 \\
\hline & No & $176(86.70 \%)$ & 177 (89.39\%) & \\
\hline \multirow[t]{5}{*}{ Education level } & Analphabetic & 12 (5.91\%) & $4(2.02 \%)$ & 0.200 \\
\hline & Basic & 99 (48.77\%) & $112(56.57 \%)$ & \\
\hline & Low & 27 (13.30\%) & 25 (12.63\%) & \\
\hline & Middle & 46 (22.66\%) & $44(22.22 \%)$ & \\
\hline & High & 19 (9.36\%) & $13(6.56 \%)$ & \\
\hline \multirow[t]{3}{*}{ Civil state } & Stable union & 76 (38.38\%) & 98 (48.28\%) & 0.055 \\
\hline & $\begin{array}{l}\text { No stable } \\
\text { union }\end{array}$ & $122(61.62 \%)$ & $105(51.72 \%)$ & \\
\hline & Missing & 5 & & \\
\hline \multirow[t]{2}{*}{ Ethnic origin } & Mixed & 70 (34.48\%) & $62(31.31 \%)$ & 0.525 \\
\hline & Caucasian & 133 (65.52\%) & 136 (68.69\%) & \\
\hline
\end{tabular}

Table 2. Risk factors of breast cancer of pre menopause, post menopause and parous women. 


\begin{tabular}{|c|c|c|c|c|c|c|c|}
\hline & & N (\%) & $\mathbf{N}(\%)$ & $\begin{array}{l}\mathrm{OR}_{\mathrm{CRUDE}} \\
(95 \% \mathrm{CI})\end{array}$ & $\mathbf{P}_{\text {LRT }}$ & $\begin{array}{l}\text { OR }_{\text {ADJUSTED }} \\
(95 \% \mathrm{CI})^{1}\end{array}$ & $\mathrm{P}_{\text {LRT }}$ \\
\hline \multicolumn{8}{|c|}{ Pre menopause women $(\mathrm{N}=181)$} \\
\hline & & $\begin{array}{c}\text { Case } \\
(\mathrm{N}=88)\end{array}$ & $\begin{array}{l}\text { Control } \\
(\mathrm{N}=93)\end{array}$ & & & & \\
\hline \multirow[t]{5}{*}{$\begin{array}{l}\text { Age } \\
\text { categories }\end{array}$} & $<30$ & $\begin{array}{l}3 \\
(3.41 \%)\end{array}$ & $4(4.3 \%)$ & $\begin{array}{l}0.750 \\
(0.08- \\
6.71)\end{array}$ & 0.818 & & \\
\hline & $31-39$ & $\begin{array}{l}28 \\
(31.82 \%)\end{array}$ & $\begin{array}{l}27 \\
(29.03 \%)\end{array}$ & $\begin{array}{l}1.037 \\
(0.19- \\
5.6)\end{array}$ & & & \\
\hline & $40-49$ & $\begin{array}{l}45 \\
(51.13 \%\end{array}$ & $\begin{array}{l}44 \\
(47.31 \%)\end{array}$ & $\begin{array}{l}1.023 \\
(0.2- \\
5.34)\end{array}$ & & & \\
\hline & $50-59$ & $\begin{array}{l}9 \\
(10.23 \%)\end{array}$ & $\begin{array}{l}15 \\
(16.13 \%)\end{array}$ & $\begin{array}{l}0.600 \\
(0.10- \\
3.63)\end{array}$ & & & \\
\hline & $\geq 60$ & $\begin{array}{l}3 \\
(3.41 \%)\end{array}$ & $\begin{array}{l}3 \\
(3.23 \%)\end{array}$ & 1 & & & \\
\hline \multirow[t]{2}{*}{$\begin{array}{l}\text { Age at } \\
\text { menarche }\end{array}$} & $<12$ & $\begin{array}{l}13 \\
(14.77 \%)\end{array}$ & $\begin{array}{l}13 \\
(13.98 \%)\end{array}$ & $\begin{array}{l}1.067 \\
(0.47- \\
2.45)\end{array}$ & 0.879 & & \\
\hline & $\geq 12$ & $\begin{array}{l}75 \\
(85.23 \%)\end{array}$ & $\begin{array}{l}80 \\
(86.02 \%)\end{array}$ & 1 & & & \\
\hline \multirow[t]{2}{*}{ Nulliparity } & Yes & $\begin{array}{l}7 \\
(7.96 \%)\end{array}$ & $\begin{array}{l}17 \\
(20.48 \%)\end{array}$ & $\begin{array}{l}0.386 \\
(0.15- \\
0.98)\end{array}$ & 0.038 & & \\
\hline & No & $\begin{array}{l}81 \\
(92.04 \%)\end{array}$ & $\begin{array}{l}76 \\
(81.72 \%)\end{array}$ & & & & \\
\hline 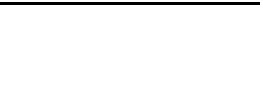 & 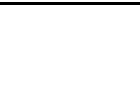 & . & & & & & \\
\hline
\end{tabular}




\begin{tabular}{|c|c|c|c|c|c|c|c|}
\hline $\begin{array}{l}\text { Oral } \\
\text { contraceptive } \\
\text { use }\end{array}$ & Yes & $\begin{array}{l}67 \\
(76.14 \%)\end{array}$ & $\begin{array}{l}37 \\
(39.78 \%)\end{array}$ & $\begin{array}{l}4.829 \\
(2.54- \\
9.18)\end{array}$ & $<0.001$ & $\begin{array}{l}3.661 \\
(1.81-7.39)\end{array}$ & $<0.001$ \\
\hline & No & $\begin{array}{l}21 \\
(23.86 \%)\end{array}$ & $\begin{array}{l}56 \\
(60.22 \%)\end{array}$ & 1 & & 1 & \\
\hline \multirow[t]{3}{*}{ Abortion } & Ever & $\begin{array}{l}24 \\
(28.57 \%)\end{array}$ & $\begin{array}{l}17 \\
(18.28 \%)\end{array}$ & $\begin{array}{l}1.788 \\
(0.88- \\
3.63)\end{array}$ & 0.105 & & \\
\hline & Never & $\begin{array}{l}60 \\
(71.43 \%)\end{array}$ & $\begin{array}{l}76 \\
(81.72 \%)\end{array}$ & 1 & & & \\
\hline & Missing & 4 & & & & & \\
\hline \multirow[t]{2}{*}{$\begin{array}{l}\text { Family } \\
\text { history }\end{array}$} & Yes & $\begin{array}{l}52 \\
(59.09 \%)\end{array}$ & $\begin{array}{l}19 \\
(20.43 \%)\end{array}$ & $\begin{array}{l}5.626 \\
(2.91- \\
10.88)\end{array}$ & $<0.001$ & $\begin{array}{l}3.791 \\
(1.85-7.77)\end{array}$ & $<0.001$ \\
\hline & No & $\begin{array}{l}36 \\
(40.91 \%)\end{array}$ & $\begin{array}{l}74 \\
(79.57 \%)\end{array}$ & 1 & & 1 & \\
\hline \multirow[t]{4}{*}{ BMI } & Obesity & $\begin{array}{l}22 \\
(25.88 \%)\end{array}$ & $\begin{array}{l}24 \\
(25.81 \%)\end{array}$ & $\begin{array}{l}1.324 \\
(0.62- \\
2.83)\end{array}$ & 0.291 & & \\
\hline & Overweight & $\begin{array}{l}36 \\
(42.35 \%)\end{array}$ & $\begin{array}{l}30 \\
(32.26 \%)\end{array}$ & $\begin{array}{l}1.733 \\
(0.87- \\
3.45)\end{array}$ & & & \\
\hline & Normal & $\begin{array}{l}27 \\
(31.77 \%)\end{array}$ & $\begin{array}{l}39 \\
(41.93 \%)\end{array}$ & & & & \\
\hline & Missing & 3 & & & & & \\
\hline \multirow[t]{2}{*}{$\begin{array}{l}\text { Waist- hip } \\
\text { ratio }\end{array}$} & $>0.8$ & $\begin{array}{l}74 \\
(86.05 \%)\end{array}$ & $\begin{array}{l}70 \\
(75.27 \%)\end{array}$ & $\begin{array}{l}2.026 \\
(0.94- \\
4.38)\end{array}$ & 0.067 & & \\
\hline & $\leq 0.8$ & $\begin{array}{l}12 \\
(13.95 \%)\end{array}$ & $\begin{array}{l}23 \\
(24.73 \%)\end{array}$ & 1 & & & \\
\hline
\end{tabular}




\begin{tabular}{|c|c|c|c|c|c|c|c|}
\hline & Missing & 2 & & & & & \\
\hline \multirow[t]{2}{*}{$\begin{array}{l}\text { Physical } \\
\text { activity }\end{array}$} & No & $\begin{array}{l}52 \\
(59.09 \%)\end{array}$ & $\begin{array}{l}52 \\
(55.91 \%)\end{array}$ & $\begin{array}{l}1.139 \\
(0.63- \\
2.06)\end{array}$ & 0.666 & & \\
\hline & Yes & $\begin{array}{l}36 \\
(40.91 \%)\end{array}$ & $\begin{array}{l}41 \\
(44.09 \%)\end{array}$ & 1 & & & \\
\hline \multirow[t]{2}{*}{ Smoking } & Ever & $\begin{array}{l}17 \\
(19.32 \%)\end{array}$ & $\begin{array}{l}17 \\
(8.43 \%)\end{array}$ & $\begin{array}{l}1.070 \\
(0.51- \\
2.26)\end{array}$ & 0.858 & & \\
\hline & Never & $\begin{array}{l}71 \\
(80.68 \%)\end{array}$ & $\begin{array}{l}76 \\
(91.57 \%)\end{array}$ & 1 & & & \\
\hline \multirow[t]{3}{*}{$\begin{array}{l}\text { Alcohol } \\
\text { consumption }\end{array}$} & Yes & $\begin{array}{l}30 \\
(34.09 \%)\end{array}$ & $\begin{array}{l}13 \\
(14.13 \%)\end{array}$ & $\begin{array}{l}3.143 \\
(1.51- \\
6.55)\end{array}$ & 0.002 & $\begin{array}{l}2,059 \\
(0.90-4.73)\end{array}$ & 0.086 \\
\hline & No & $\begin{array}{l}58 \\
(65.91 \%)\end{array}$ & $\begin{array}{l}79 \\
(85.87 \%)\end{array}$ & & & 1 & \\
\hline & Missing & & 1 & & & & \\
\hline \multicolumn{8}{|c|}{ Post menopause women $(\mathrm{N}=401)$} \\
\hline & & $\begin{array}{l}\text { Case } \\
(\mathrm{N}= \\
203)\end{array}$ & $\begin{array}{l}\text { Control } \\
\qquad \begin{array}{c}(\mathrm{N}= \\
198)\end{array}\end{array}$ & & & & \\
\hline \multirow[t]{3}{*}{$\begin{array}{l}\text { Age } \\
\text { categories }\end{array}$} & $<40$ & $\begin{array}{l}5 \\
(2.46 \%)\end{array}$ & $\begin{array}{l}1 \\
(0.50 \%)\end{array}$ & $\begin{array}{l}5.735 \\
(0.64- \\
51.54)\end{array}$ & $<0.001$ & & \\
\hline & $40-49$ & $\begin{array}{l}29 \\
(14.29 \%)\end{array}$ & $\begin{array}{l}4 \\
(2.02 \%)\end{array}$ & $\begin{array}{l}8.316 \\
(2.65- \\
26.06)\end{array}$ & & & \\
\hline & $50-59$ & $\begin{array}{l}66 \\
(32.51 \%)\end{array}$ & $\begin{array}{l}92 \\
(46.47 \%)\end{array}$ & $\begin{array}{l}0.823 \\
(0.47- \\
1.44)\end{array}$ & & & \\
\hline
\end{tabular}




\begin{tabular}{|c|c|c|c|c|c|c|c|}
\hline & $60-69$ & $\begin{array}{l}69 \\
(33.99 \%)\end{array}$ & $\begin{array}{l}62 \\
(31.31 \%)\end{array}$ & $\begin{array}{l}1.277 \\
(0.72- \\
2.27)\end{array}$ & & & \\
\hline & $\geq 70$ & $\begin{array}{l}34 \\
(16.75 \%)\end{array}$ & $\begin{array}{l}39 \\
(19.70 \%)\end{array}$ & 1 & & & \\
\hline \multirow[t]{3}{*}{$\begin{array}{l}\text { Age at } \\
\text { menarche }\end{array}$} & $<12$ & $\begin{array}{l}29 \\
(14.43 \%)\end{array}$ & $\begin{array}{l}16 \\
(8.08 \%)\end{array}$ & $\begin{array}{l}1.918 \\
(1.01- \\
3.66)\end{array}$ & 0.044 & & \\
\hline & $\geq 12$ & $\begin{array}{l}172 \\
(85.57 \%)\end{array}$ & $\begin{array}{l}182 \\
(91.92 \%)\end{array}$ & 1 & & & \\
\hline & Missing & 2 & & & & & \\
\hline \multirow[t]{2}{*}{ Nulliparity } & Yes & $\begin{array}{l}32 \\
(15.76 \%)\end{array}$ & $\begin{array}{l}17 \\
(8.59 \%)\end{array}$ & $\begin{array}{l}1.992 \\
(1.07- \\
3.72)\end{array}$ & 0.027 & $\begin{array}{l}2.667 \\
(1.30-5.50)\end{array}$ & 0.070 \\
\hline & No & $\begin{array}{l}171 \\
(84.24 \%)\end{array}$ & $\begin{array}{l}181 \\
(91.41 \%)\end{array}$ & 1 & & 1 & \\
\hline \multirow[t]{2}{*}{$\begin{array}{l}\text { Oral } \\
\text { contraceptive } \\
\text { use }\end{array}$} & Yes & $\begin{array}{l}122 \\
(60.10 \%)\end{array}$ & $\begin{array}{l}61 \\
(30.81 \%)\end{array}$ & $\begin{array}{l}3.383 \\
(2.24- \\
5.12)\end{array}$ & $<0.001$ & $\begin{array}{l}3.086 \\
(1.85-5.79)\end{array}$ & $<0.001$ \\
\hline & No & $\begin{array}{l}81 \\
(39.90 \%)\end{array}$ & $\begin{array}{l}137 \\
(69.19 \%)\end{array}$ & 1 & & & \\
\hline \multirow[t]{3}{*}{ Abortion } & Ever & $\begin{array}{l}53 \\
(27.75 \%)\end{array}$ & $\begin{array}{l}51 \\
(26.02 \%)\end{array}$ & $\begin{array}{l}1.092 \\
(0.70- \\
1.71)\end{array}$ & 0.701 & & \\
\hline & Never & $\begin{array}{l}138 \\
(72.25 \%)\end{array}$ & $\begin{array}{l}145 \\
(73.98 \%)\end{array}$ & 1 & & 1 & \\
\hline & Missing & 12 & 2 & & & & \\
\hline $\begin{array}{l}\text { Family } \\
\text { history }\end{array}$ & Yes & $\begin{array}{l}115 \\
(56.55 \%)\end{array}$ & $\begin{array}{l}47 \\
(23.74 \%)\end{array}$ & $\begin{array}{l}4.199 \\
(2.73- \\
6.45)\end{array}$ & $<0.001$ & $\begin{array}{l}3.576 \\
(2.21-5.79)\end{array}$ & $<0.001$ \\
\hline
\end{tabular}




\begin{tabular}{|c|c|c|c|c|c|c|c|}
\hline & No & $\begin{array}{l}88 \\
(43.35 \%)\end{array}$ & $\begin{array}{l}151 \\
(76.26 \%)\end{array}$ & 1 & & 1 & \\
\hline \multirow[t]{4}{*}{ BMI } & Obesity & $\begin{array}{l}68 \\
(34.87 \%)\end{array}$ & $\begin{array}{l}40 \\
(20.20 \%)\end{array}$ & $\begin{array}{l}2.386 \\
(1.42- \\
4.00)\end{array}$ & 0.030 & $\begin{array}{l}2.117 \\
(1.15-3.88)\end{array}$ & 0.048 \\
\hline & Overweight & $\begin{array}{l}70 \\
(36.00 \%)\end{array}$ & $\begin{array}{l}78 \\
(39.40 \%)\end{array}$ & $\begin{array}{l}1.260 \\
(0.79- \\
2.01)\end{array}$ & & $\begin{array}{l}1.271 \\
(0.74-2.19)\end{array}$ & \\
\hline & Normal & $\begin{array}{l}57 \\
(29.23 \%)\end{array}$ & $\begin{array}{l}80 \\
(40.40 \%)\end{array}$ & 1 & & 1 & \\
\hline & Missing & 8 & & & & & \\
\hline \multirow[t]{3}{*}{$\begin{array}{l}\text { Waist- hip } \\
\text { ratio }\end{array}$} & $>0.8$ & $\begin{array}{l}182 \\
(90.10 \%)\end{array}$ & $\begin{array}{l}182 \\
(91.92 \%)\end{array}$ & $\begin{array}{l}0.800 \\
(0.40- \\
1.59)\end{array}$ & 0.524 & & \\
\hline & $\leq 0.8$ & $\begin{array}{l}20 \\
(9.90 \%)\end{array}$ & $\begin{array}{l}16 \\
(8.08 \%)\end{array}$ & 1 & & & \\
\hline & Missing & 1 & & & & & \\
\hline \multirow[t]{2}{*}{$\begin{array}{l}\text { Physical } \\
\text { activity }\end{array}$} & No & $\begin{array}{l}94 \\
(46.30 \%)\end{array}$ & $\begin{array}{l}110 \\
(55.56 \%)\end{array}$ & $\begin{array}{l}0.690 \\
(0.47- \\
1.02)\end{array}$ & 0.064 & & \\
\hline & Yes & $\begin{array}{l}109 \\
(53.70 \%)\end{array}$ & $\begin{array}{l}88 \\
(44.44 \%)\end{array}$ & 1 & & & \\
\hline \multirow[t]{2}{*}{ Smoking } & Ever & $\begin{array}{l}91 \\
(44.83 \%)\end{array}$ & $\begin{array}{l}74 \\
(37.37 \%)\end{array}$ & $\begin{array}{l}1.361 \\
(0.91- \\
2.03)\end{array}$ & 0.129 & & \\
\hline & Never & $\begin{array}{l}112 \\
(55.17 \%)\end{array}$ & $\begin{array}{l}124 \\
(62.63 \%)\end{array}$ & 1 & & & \\
\hline $\begin{array}{l}\text { Alcohol } \\
\text { consumption }\end{array}$ & Yes & $\begin{array}{l}56 \\
(27.59 \%)\end{array}$ & $\begin{array}{l}13 \\
(6.57 \%)\end{array}$ & $\begin{array}{l}5.421 \\
(2.86- \\
10.29)\end{array}$ & $<0.001$ & $\begin{array}{l}4.21(2.08- \\
8.50)\end{array}$ & $<0.001$ \\
\hline
\end{tabular}




\begin{tabular}{|c|c|c|c|c|c|c|c|}
\hline & No & $\begin{array}{l}147 \\
(72.41 \%)\end{array}$ & $\begin{array}{l}185 \\
(93.43 \%)\end{array}$ & & & 1 & \\
\hline \multicolumn{8}{|c|}{ Parous women only $(\mathrm{N}=509)$} \\
\hline & & $\begin{array}{l}\text { Case } \\
(\mathrm{N}= \\
252)\end{array}$ & $\begin{array}{l}\text { Control } \\
\begin{array}{l}(\mathrm{N}= \\
257)\end{array}\end{array}$ & & & & \\
\hline & & N (\%) & N (\%) & $\begin{array}{l}\mathrm{OR}_{\mathrm{CRUDE}} \\
(95 \% \mathrm{CI})\end{array}$ & $P_{\text {LRT }}$ & $\begin{array}{l}\text { OR }_{\text {ADJUSTED }} \\
(95 \% \mathrm{CI})^{2}\end{array}$ & $\mathrm{P}_{\mathrm{LRT}}$ \\
\hline \multirow[t]{6}{*}{$\begin{array}{l}\text { Age } \\
\text { categories }\end{array}$} & $<30$ & $\begin{array}{l}3 \\
(1.19 \%)\end{array}$ & $\begin{array}{l}3 \\
(1.17 \%)\end{array}$ & $\begin{array}{l}1.400 \\
(0.26- \\
7.52)\end{array}$ & 0.008 & & \\
\hline & $31-39$ & $\begin{array}{l}31 \\
(12.30 \%)\end{array}$ & $\begin{array}{l}25 \\
(9.73 \%)\end{array}$ & $\begin{array}{l}1.736 \\
(0.83- \\
3.62)\end{array}$ & & & \\
\hline & $40-49$ & $\begin{array}{l}66 \\
(26.19 \%)\end{array}$ & $\begin{array}{l}41 \\
(15.95 \%)\end{array}$ & $\begin{array}{l}2.254 \\
(1.18- \\
4.29)\end{array}$ & & & \\
\hline & $50-59$ & $\begin{array}{l}62 \\
(24.60 \%)\end{array}$ & $\begin{array}{l}95 \\
(36.96 \%)\end{array}$ & $\begin{array}{l}0.914 \\
(0.50- \\
1.67)\end{array}$ & & & \\
\hline & $60-69$ & $\begin{array}{l}65 \\
(25.80 \%)\end{array}$ & $\begin{array}{l}58 \\
(22.57 \%)\end{array}$ & $\begin{array}{l}1.569 \\
(0.84- \\
2.93)\end{array}$ & & & \\
\hline & $\geq 70$ & $\begin{array}{l}25 \\
(9.92 \%)\end{array}$ & $\begin{array}{l}35 \\
(13.62 \%)\end{array}$ & 1 & & & \\
\hline \multirow[t]{2}{*}{$\begin{array}{l}\text { Menopause } \\
\text { status }\end{array}$} & Pre & $\begin{array}{l}80 \\
(31.75 \%)\end{array}$ & $\begin{array}{l}77 \\
(29.96 \%)\end{array}$ & $\begin{array}{l}1.087 \\
(0.75- \\
1.58)\end{array}$ & 0.663 & & \\
\hline & Post & $\begin{array}{l}172 \\
(68.25 \%)\end{array}$ & $\begin{array}{l}180 \\
(70.04 \%)\end{array}$ & 1 & & & \\
\hline
\end{tabular}




\begin{tabular}{|c|c|c|c|c|c|c|c|}
\hline $\begin{array}{l}\text { Age at } \\
\text { menarche }\end{array}$ & $<12$ & $\begin{array}{l}37 \\
(14.68 \%)\end{array}$ & $\begin{array}{l}22 \\
(8.56 \%)\end{array}$ & $\begin{array}{l}1.838 \\
(1.05- \\
3.22)\end{array}$ & 0.030 & & \\
\hline & $\geq 12$ & $\begin{array}{l}215 \\
(85.32 \%)\end{array}$ & $\begin{array}{l}235 \\
(91.44 \%)\end{array}$ & 1 & & & \\
\hline \multirow[t]{4}{*}{$\begin{array}{l}\text { Number of } \\
\text { children }\end{array}$} & 1 & $\begin{array}{l}40 \\
(15.94 \%)\end{array}$ & $\begin{array}{l}55 \\
(21.40 \%)\end{array}$ & $\begin{array}{l}0.568 \\
(0.34- \\
0.95)\end{array}$ & 0.081 & $\begin{array}{l}0.397 \\
(0.21-0.76)\end{array}$ & 0.016 \\
\hline & $2-3$ & $\begin{array}{l}124 \\
(49.40 \%)\end{array}$ & $\begin{array}{l}134 \\
(52.14 \%)\end{array}$ & $\begin{array}{l}0.723 \\
(0.49- \\
1.08)\end{array}$ & & $\begin{array}{l}0.621 \\
(0.38-1.02)\end{array}$ & \\
\hline & $>3$ & $\begin{array}{l}87 \\
(34.66 \%)\end{array}$ & $\begin{array}{l}68 \\
(26.46 \%)\end{array}$ & 1 & & 1 & \\
\hline & Missing & 1 & & & & & \\
\hline \multirow[t]{4}{*}{$\begin{array}{l}\text { Age at first } \\
\text { life birth }\end{array}$} & $<20$ & $\begin{array}{l}90 \\
(36.15 \%)\end{array}$ & $\begin{array}{l}103 \\
(40.08 \%)\end{array}$ & $\begin{array}{l}1.143 \\
(0.64- \\
2.05)\end{array}$ & 0.288 & & \\
\hline & 20- 29 & $\begin{array}{l}133 \\
(53.41 \%)\end{array}$ & $\begin{array}{l}120 \\
(46.69 \%)\end{array}$ & $\begin{array}{l}1.449 \\
(0.82- \\
2.56)\end{array}$ & & & \\
\hline & $\geq 30$ & $\begin{array}{l}26 \\
(10.44 \%)\end{array}$ & $\begin{array}{l}34 \\
(13.23 \%)\end{array}$ & 1 & & & \\
\hline & Missing & 3 & & & & & \\
\hline \multirow[t]{2}{*}{$\begin{array}{l}\text { Reproductive } \\
\text { period }^{3}\end{array}$} & $\leq 10$ & $\begin{array}{l}139 \\
(65.57 \%)\end{array}$ & $\begin{array}{l}138 \\
(67.98 \%)\end{array}$ & $\begin{array}{l}0.897 \\
(0.60- \\
1.35)\end{array}$ & 0.602 & & \\
\hline & $>10$ & $\begin{array}{l}73 \\
(34.43 \%)\end{array}$ & $\begin{array}{l}65 \\
(32.02 \%)\end{array}$ & 1 & & & \\
\hline $\begin{array}{l}\text { Lifetime } \\
\text { breastfeeding }\end{array}$ & Never & $\begin{array}{l}32 \\
(12.75 \%)\end{array}$ & $\begin{array}{l}37 \\
(14.40 \%)\end{array}$ & $\begin{array}{l}0.799 \\
(0.47-\end{array}$ & 0.571 & & \\
\hline
\end{tabular}




\begin{tabular}{|c|c|c|c|c|c|c|c|}
\hline & & & & 1.37) & & & \\
\hline & $\leq 12$ & $\begin{array}{l}101 \\
(40.24 \%)\end{array}$ & $\begin{array}{l}111 \\
(43.19 \%)\end{array}$ & $\begin{array}{l}0.841 \\
(0.58- \\
1.22)\end{array}$ & & & \\
\hline & $>12$ & $\begin{array}{l}118 \\
(47.01 \%)\end{array}$ & $\begin{array}{l}109 \\
(42.41 \%)\end{array}$ & 1 & & & \\
\hline & Missing & 1 & & & & & \\
\hline \multirow[t]{2}{*}{$\begin{array}{l}\text { Oral } \\
\text { contraceptive } \\
\text { use }\end{array}$} & Yes & $\begin{array}{l}177 \\
(70.24 \%)\end{array}$ & $\begin{array}{l}87 \\
(33.85 \%)\end{array}$ & $\begin{array}{l}4.611 \\
(3.17- \\
6.70)\end{array}$ & $<0.001$ & $\begin{array}{l}3.785 \\
(2.47-5.81)\end{array}$ & $<0.001$ \\
\hline & No & $\begin{array}{l}75 \\
(29.76 \%)\end{array}$ & $\begin{array}{l}170 \\
(66.15 \%)\end{array}$ & 1 & & 1 & \\
\hline \multirow[t]{3}{*}{ Abortion } & Ever & $\begin{array}{l}75 \\
(29.88 \%)\end{array}$ & $\begin{array}{l}68 \\
(26.46 \%)\end{array}$ & $\begin{array}{l}1.184 \\
(0.80- \\
1.74)\end{array}$ & 0.391 & & \\
\hline & Never & $\begin{array}{l}176 \\
(70.12 \%)\end{array}$ & $\begin{array}{l}189 \\
(73.54 \%)\end{array}$ & 1 & & & \\
\hline & Missing & 1 & & & & & \\
\hline \multirow[t]{2}{*}{$\begin{array}{l}\text { Family } \\
\text { history }\end{array}$} & Yes & $\begin{array}{l}148 \\
(58.73 \%)\end{array}$ & $\begin{array}{l}58 \\
(22.57 \%)\end{array}$ & $\begin{array}{l}4.883 \\
(3.32- \\
7.18)\end{array}$ & $<0.001$ & $\begin{array}{l}3.899 \\
(2.53-6.02)\end{array}$ & $<0.001$ \\
\hline & No & $\begin{array}{l}104 \\
(41.27 \%)\end{array}$ & $\begin{array}{l}199 \\
(77.43 \%)\end{array}$ & 1 & & 1 & \\
\hline \multirow[t]{3}{*}{ BMI } & Obesity & $\begin{array}{l}85 \\
(34.98 \%)\end{array}$ & $\begin{array}{l}58 \\
(22.57 \%)\end{array}$ & $\begin{array}{l}2.198 \\
(1.40- \\
3.46)\end{array}$ & 0.003 & & \\
\hline & Overweight & $\begin{array}{l}90 \\
(37.04 \%)\end{array}$ & $\begin{array}{l}97 \\
(37.74 \%)\end{array}$ & $\begin{array}{l}1.392 \\
(0.91- \\
2.12)\end{array}$ & & & \\
\hline & Normal & 68 & 102 & 1 & & 1 & \\
\hline
\end{tabular}




\begin{tabular}{|c|c|c|c|c|c|c|c|}
\hline & & (27.98\%) & (39.69\%) & & & & \\
\hline & Missing & 9 & & & & & \\
\hline \multirow[t]{3}{*}{$\begin{array}{l}\text { Waist- hip } \\
\text { ratio }\end{array}$} & $>0.8$ & $\begin{array}{l}222 \\
(89.16 \%)\end{array}$ & $\begin{array}{l}224 \\
(87.16 \%)\end{array}$ & $\begin{array}{l}1.211 \\
(0.71- \\
2.08)\end{array}$ & 0.487 & & \\
\hline & $\leq 0.8$ & $\begin{array}{l}27 \\
(10.84 \%)\end{array}$ & $\begin{array}{l}33 \\
(12.84 \%)\end{array}$ & 1 & & & \\
\hline & Missing & 3 & & & & & \\
\hline \multirow[t]{2}{*}{$\begin{array}{l}\text { Physical } \\
\text { activity }\end{array}$} & No & $\begin{array}{l}129 \\
(51.19 \%)\end{array}$ & $\begin{array}{l}144 \\
(56.03 \%)\end{array}$ & $\begin{array}{c}0.823 \\
(0.58- \\
1.17)\end{array}$ & 0.273 & & \\
\hline & Yes & $\begin{array}{l}123 \\
(48.81 \%)\end{array}$ & $\begin{array}{l}113 \\
(43.97 \%)\end{array}$ & 1 & & & \\
\hline \multirow[t]{2}{*}{ Smoking } & Ever & $\begin{array}{l}99 \\
(39.29 \%)\end{array}$ & $\begin{array}{l}86 \\
(33.46 \%)\end{array}$ & $\begin{array}{l}1.287 \\
(0.90- \\
1.85)\end{array}$ & 0.172 & & \\
\hline & Never & $\begin{array}{l}153 \\
(60.71 \%)\end{array}$ & $\begin{array}{l}171 \\
(66.54 \%)\end{array}$ & 1 & & & \\
\hline \multirow[t]{3}{*}{$\begin{array}{l}\text { Alcohol } \\
\text { consumption }\end{array}$} & Yes & $\begin{array}{l}77 \\
(30.56 \%)\end{array}$ & $\begin{array}{l}23 \\
(8.98 \%)\end{array}$ & $\begin{array}{l}4.457 \\
(2.69- \\
7.39)\end{array}$ & $<0.001$ & $\begin{array}{l}2.991 \\
(1.69-5.28)\end{array}$ & $<0.001$ \\
\hline & No & $\begin{array}{l}175 \\
(69.44 \%)\end{array}$ & $\begin{array}{l}233 \\
(91.02 \%)\end{array}$ & 1 & & 1 & \\
\hline & Missing & & 1 & & & & \\
\hline
\end{tabular}

Odds ratios (OR), confidence intervals (95\% CI) and significance level of likelihood ratio tests $\left(\mathrm{P}_{\mathrm{LRT}}\right)$ of variables are shown for cases stratified for pre and post menopause, respectively, parous women. Control served as reference group. Variables of univariate analysis $\left(\mathrm{OR}_{\mathrm{CRUDE}}\right)$ were used for modelling (OR $\left.\mathrm{OR}_{\mathrm{AJUSTED}}\right)$. 
${ }^{1}$ Adjusted for age as continuous variable, age at menarche and smoking; ${ }^{2}$ Adjusted for age as continuous variable, age at menarche and menopause status. 